\title{
CALL FOR REVIEWERS
}

RBM: A Journal of Rare Books, Manuscripts, and Cultural Heritage will be introducing a Reviews feature beginning with the Fall 2010 issue. RBM is interested in reviewing new books, periodicals, and reports; exhibition, book, and auction catalogs; and databases, Web sites, blogs, and other electronic resources, pertaining to the world inhabited by special collections libraries and cultural heritage institutions.

Please contact the Reviews editor if you are interested in reviewing for $R B M$.

Include your name and contact information (street address, phone, e-mail) as well as your title and areas of interest or expertise. Items currently available for review can be found at www.shelfari.com/o1514576998/shelf, but potential reviewers are welcome to suggest other resources they are interested in reviewing.

Christine DeZelar-Tiedman

Reviews Editor, $R B M$

University of Minnesota Libraries

160 Wilson Library, 309 19th Ave. S

Minneapolis, MN 55455

(612) 625-0381

dezel002@umn.edu

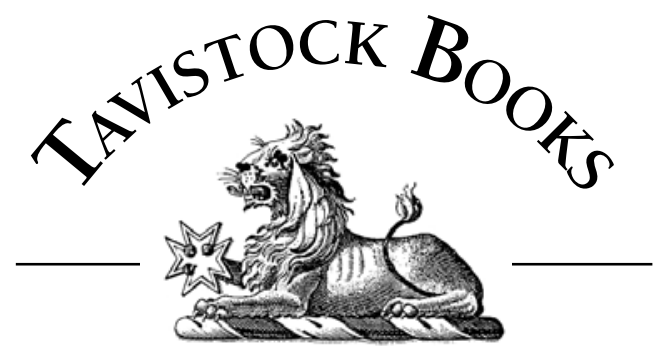

First Editions, Rare \& Collectible Books in Most Subject Areas

\section{WWW.TAVBOOKS.COM}

AB

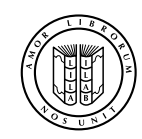

1503 WEBSTER STREET • ALAMEDA, CALIFORNIA 94501

T: $510.814 .0480 \bullet F: 510.814 .0486 \bullet v j z @ t a v b o o k s . c o m$ 